\title{
People and Water: Empirics of Calabar Municipality, Cross River State, Nigeria
}

\author{
${ }^{1}$ Philip O. Ubugha, ${ }^{2}$ Francis Okpiliya, ${ }^{3}$ Chukwudi G. Njoku*, ${ }^{4}$ Prince-Charles O. Itu, \\ ${ }^{5}$ Tonye I. Ojoko, ${ }^{6}$ Frank O. Erhabor \\ 1,2,3,4,5 Department of Geography and Environmental Science, University of Calabar, \\ Calabar, Cross River State, Nigeria
}

${ }^{6}$ Department of Geography and Environmental Management, Ahmadu Bello University, Zaria, Kaduna State, Nigeria

\begin{abstract}
Water stress is emerging as the most critical resource issue facing humanity. The world's population and water demand continues to expand rapidly and is worsened where proper measures are not taken like in Calabar Municipality of Cross River State, Nigeria where abundance of water in its natural state does not imply a wealth of the resource in homes. A total of 384 questionnaires were distributed randomly within the Municipality and data were also collected from the National Population Commission and Cross River State Water Board Limited (CRSWBL). Results showed that the population of the area is on an upward trend. Geographic access was considerably good in the area with $65 \%$ of residents at convenient distance $(<200$ meters) to water source, although $49 \%$ relied on privately owned boreholes. The volume of water used by the residents daily was not sufficient based on the World Health Organization 50 litre per-person-per-day standard, but still, $56.7 \%$ of people submitted that the water situation was decent in the area. Further analysis revealed there was significant relationship between population growth and volume of pipe-borne water supplied as well as consumed. Water use was also significantly influenced by household size, income and cost of water. Based on the findings, the need for new policies in water and population management, use of recent geospatial technologies as well as diligence by CRSWBL in their operations was emphasized to ensure sustainable water provision in the Municipality.
\end{abstract}

Keywords: Population, water cost, water consumption, Calabar Municipality

\section{BACKGROUND OF THE STUDY}

Water remains a finite natural resource that cannot be created but only be recycled. It is estimated that water consumption doubles the rate of population growth (Population Institute, 2010). If this increase in population growth and water use trends persists, it is estimated that the demand for water will exceed its supply and availability and many will be living in water stress/scarce regions in the near future. This situation is made worse by the fact that developing countries often have the highest population growth rate through both natural means and migration, bringing in more people into a place that is already stressed up by population. Water stress countries refer to countries with fewer than $1000 \mathrm{~m}^{3}$ of water per person per year and water scarce countries refers to countries with fewer than $700 \mathrm{~m}^{3}$ per person per year (Human Development Report, 2006). In Africa, water crisis will aggravate in the near future if immediate and pragmatic steps are not taken to arrest this social problem that is fast growing. The present and future availability of adequate and safe water supply to man is being threatened by the overdraft of both surface and ground water to meet the need of rapidly growing human population.

The world population growth rate in the last 50 years was so unprecedented that it grew above the projected rate. According to United Nations Population Division, (2008), the world population was 2.5 billion 1980, it rose to 6.5 billion in 2005 and by 2050; the population will rise above 9 billion. Drastic increase in population started when agriculture was introduced, communities evolved that could support many people. Population growth was accelerated after the industrial revolution in the 18th century when living standard rose, health care improved, famine and epidemics reduced in some regions. Calabar, though surrounded by water still faces the problem of water accessibility. The 
problem of water supply and demand still persist in Calabar due to high population explosion and the failure of government to integrate the principle of sustainable development into the country's policies and programmes (Eni, Digha and Abua, 2015).

The relationship between people and water is rather less emphasized. The number of people on earth is expanding by 80 million people annually, growing the demand for water by as much as 64 billion $\mathrm{m} 3$ a year (Population Institute, 2010). Growth in population implies increasing demand for water for all known uses (Population Action International, 2011). Rapid population growth and the resultant urbanization can uncover more people to water scarcities, with adverse repercussions for general wellbeing and security. These demographic developments, in addition to swelling water consumption, will be an enormous development challenge (Bates, Kundzewicz, Wu and Palutikof, 2008). At the household level, demand for water is determined by demographic factors including household size, age structure and income composition.

The rate of urbanization in Nigeria and Calabar in particular has greatly increased leading to pressure on the environment and infrastructure. Calabar as one of the major urban centres in Nigeria has become a place where migrants seeking adventure and livelihood converge, thereby increasing the population of the area. As population increases, the quest to grow the economy and create jobs for the growing population also increases, hence the need to develop appropriate and sustainable water management schemes to ensure water supply for the present and the future generation. Preliminary survey by the authors emphasized that the rapid population growth in Calabar has aggravated the existing water problem in the city. The study is limited to Calabar Municipality, one of the 2 Local Government Areas (LGA) that make up Calabar Metropolis which is the Capital of Cross River State and is situated in the South-South geopolitical zone of Nigeria (Figure 1). It is made up of 10 council wards and had a population of 122,229 in 1991 and 179,392 in 2006 according to the National Population Commission (NPC).

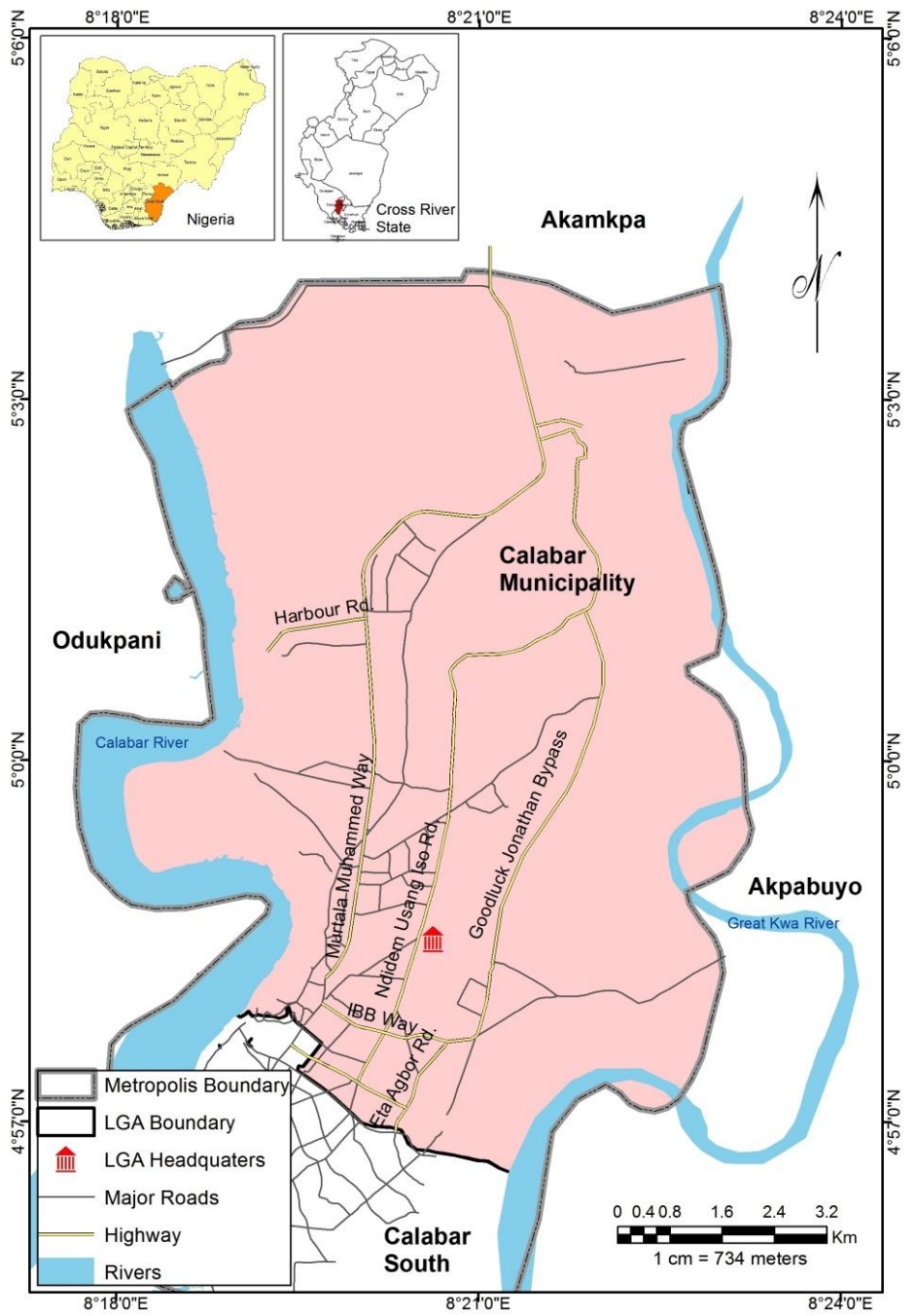

Figure 1. Study area (Source: Cross River Geographic Information Agency, 2016) 


\section{LITERATURE REVIEW}

The issue of water stress due to population growth and other factors is not new and has been in the fore-front of academic discuss. Rapid population increase in a country, especially in the developing climes, is a threat to the environment through strong action of crop cultivation, poor pattern of urban growth, the development of industries and damage to the natural ecosystem. UNPD (2006) analysed population change from A.D. 1 to 2050. The analysis revealed that the world population was 300 million by A.D. 1, grow to 760 million in 1750 and reached 1 billion around 1800. The world population was about 2.5 billion in 1980 . It rose to 6.5 billion in 2005 , and by 2050 , the population may rise above 9 billion.

Nhapi (2009) investigated the water situation in Harare, Zimbabwe and revealed that Harare has sufficient water to meet its water needs although water quantity will soon be a serious issue. It was recommended that to avoid the problem of water shortage in the near future, a corporate body, government political will and with a degree of freedom be saddled with the responsibility of providing water for Harare and its environs. Oyegoke, Adeyemi and Sojobi (2012), took a study on the challenges of water supply for a megacity. A case study of Lagos Metropolis revealed that the water supply challenges of Lagos State needs a paradigm shift. He stated that "assimilation and adoption of best practice from developed countries and entrenchment of effective project management by all stakeholders will go a long way in ensuring sustainable water supply for the teeming water demand of the state".

Further, Bello and Tuna (2014) carried out a research on evaluation of potable water demand and supply in Kano State, Nigeria. The study revealed that both Kano State Water Board Supply and Sanitation Agency (RUWASA) that is responsible for water supply in the state is yet to provide adequate water to the over 12 million people of Kano State. The study further revealed that the total water demand of Kano State per day is 979 million litres (mld) and the supply is 270 mld. The difference is 705 mld. It shows that only 27.7 percent of the total water demanded is usually supplied. Ezenwaji et al., (2016), made an investigation into the residential water demand and supply in Enugu Metropolitan Area, Nigeria and result showed that Enugu Metropolitan Area has a wide and prolonged water supply shortages. The literature supports the study as it buttresses the fact that there exist spatial variation of water scarcity and availability as well as population density.

To recommend measures for improving access to water, Njoku, et al., (2017) modeled pipe-borne water distribution in Calabar using Epanet spatial modeling tools. The authors noted that the problem of water stress is compounded by the poor distribution system. They identified locations with abnormal water pressures and flow rates which deter equitability in supply from CRSWBL to the populace. Based on their findings, they recommended that the existing pipe-borne water network of Calabar be reassessed. Generally, increase in population leads to increase in water consumption. Eni (2010) in his thesis on domestic water supply in Abi local government area; revealed that the demand for water is highest during festive periods due to in-flux of visitors which leads to temporary increase of population within the period. Farnazeh (2001), in his work on population trends and challenges in Middle East and North Africa (MENA) concluded that "taking exception to addressing water problem in MENA is made worse by the region's population pressure". In a nutshell, these literatures have buttressed the problem of water stress and scarcity at different places and have also showed the role of people in the situation.

\section{Materials and Methods}

Data for this study was acquired mainly from primary sources using questionnaires and a handheld Global Positioning System (GPS) for acquiring coordinates of questionnaire administration location. Secondary sources included the 1991 and 2006 census data from the NPC and Cross River State Water Board Limited (CRSWBL) monthly data of volume of water consumed and supplied to the Municipality from 2006 to 2015 . A total of 384 samples were drawn from the total population of the study area adopting the Smith (2000) formula. The questionnaires were distributed randomly within the wards strata of the area after dividing the proportion for each ward systematically.

GIS techniques were used to create maps that showed spatial variation in usage and expenditure on water, as well as the population density of the area, using the Environmental Systems Research Institute (ESRI) ArcMap software. Data obtained from the field were inputted as attributes of the sample points layer and the Inverse Distance Weighted (IDW) interpolation method was applied to 
derive the maps. Interpolating the data becomes necessary since all the households in the Municipality can't be sampled. The assumption that makes interpolation a viable option is that things that are close together tend to have similar characteristics (ESRI, 2013). To derive the temporal population of the area, the population of Calabar Municipality of 1991 census given by National Population Commission was projected to 2015 using 2.54 percent population growth rate per year, given by World Bank for Nigeria in 2015. The formula used was: $\mathrm{Pn}=\mathrm{Po}(1+\mathrm{r} / 100) n$ (Equation 1); where $\mathrm{Pn}=$ Projected population; $\mathrm{Po}=$ Base year population; $\mathrm{r}=$ Population growth rate, $\mathrm{n}=$ Interval between years

\section{RESULTS AND DISCUSSIONS}

\subsection{Population Trend in Calabar Municipality}

The population trend in the Municipality was examined. The population of Calabar Municipality according to the 1991 census by NPC was122, 229 and 179,392 in 2006. The figure was projected to the year 2015 using 2.54 population growth rate. As shown on Figure 2, the population of Calabar Municipality in in the $1^{\text {st }}$ year under consideration (2006) was 188,424 and 221,629 in the $10^{\text {th }}$ year (2015), an indication that the population of the area is on the increase and would most likely influence water demands, since more people in the area would mean more water use, yet water is finite. Figure 3 is a pictorial representation showing the population density of the study area for the year 2015 as projected. It revealed that Ward 1 is the most populated area having a population density between 100,000 to 145,000 and 75000 to 100000 persons. For most parts of the area, the density was 25,000 to 50,000 persons, except for parts of Ward 4 and parts of Wards 3, 9 and 10 which are suburbs with less denser population.

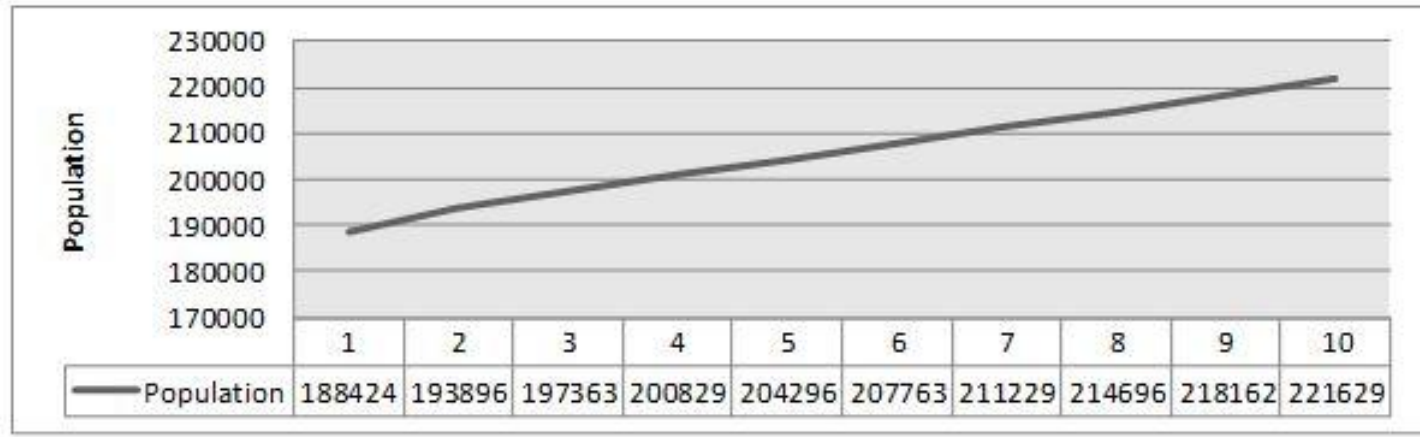

Figure 2. Population growth in Calabar Municipality (2006 to 2015). Source: Authors field work, 2015.

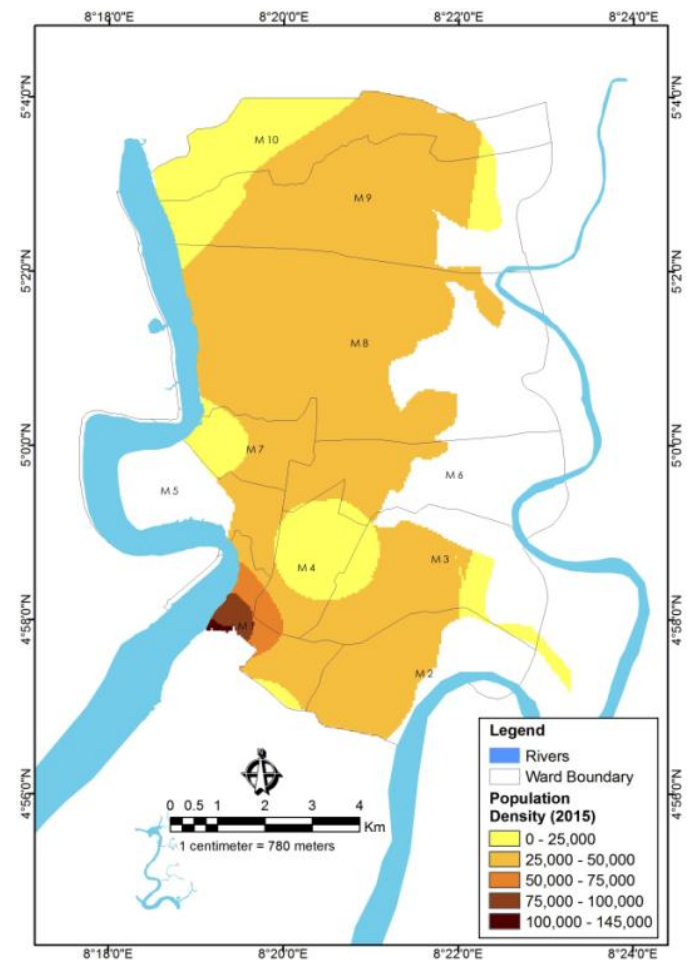

Figure 3. 2015 population density map of Calabar Municipality (Source: Authors, 2015) 


\subsection{Socio-economics Attributes of Residents}

The result from the field survey revealed that literacy level was high in the Municipality. While 40.9 percent had tertiary education, 47.4 percent had secondary education, 6.0 had primary education while 22 respondents had no formal education. The income of the residents showed less variation. Only 2.6 percent earned more than 100000 Naira, 36.3 percent earned between 41000 to 70000, 23.7 percent earned between 21000 to $40000,22.7$ percent earned less than 10000, 14.1 percent earn between 11000 to 20000 , while 13.3 percent earn above 70000 . This proves that there are more low and medium income earners in the city that the high earners. Further, most household in the area had 3 and 4 persons, 26 percent for the former and 27.3 for the later. 4 percent had more than 6 persons in their houses and 18 percent had only 1 person. Others include 11.2 percent for 2 persons, and 13.5 for 5 persons.

\subsection{Proximity to Water Source}

Figure 4 makes known the distances respondents cover to get to a source of water supply. According to the United Nations Population Division [UNPD], (2000), geographic access to portable water is measured by the fraction of populace with access to sufficient volume of clean water situated in or at a distance not far away from the user's dwelling. That is at a convenient distance of at least 200 meters to acquire the water where it is not present within residence. Analysis revealed that 63.5 percent of the residents cover the permissible distance of less than 200 meters while the other 36.5 are deprived. 21.6 percent cover a distance between $201 \mathrm{~m}$ to 400 meters, while a distance of 401 to 600 meters and above 600 meters is covered by 9.9 percent and 4.9 percent respectively. Geographic access to water is thus considerable good in the Municipality.

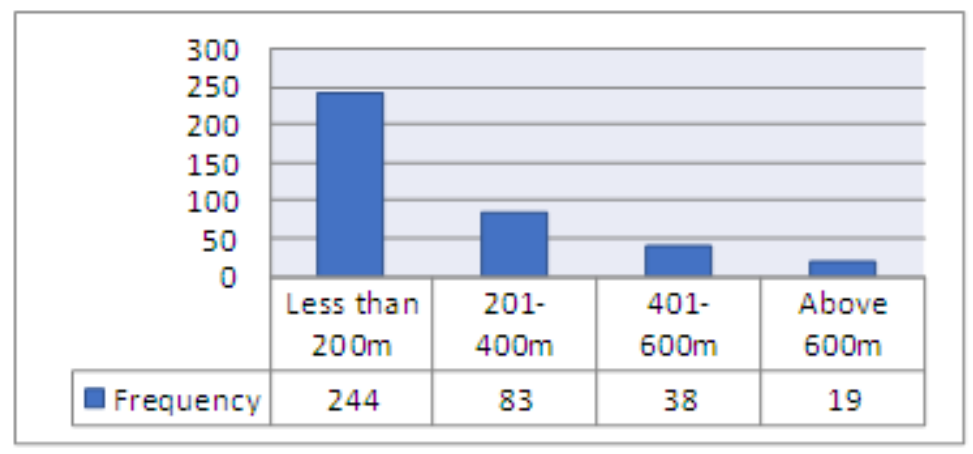

Figure 4. Proximity to water source in the Municipality (Source: Authors field work, 2015)

Likewise, Figure 5 shows the sources of water supply in the study area. It reveals that 49 percent of residents rely on privately operated boreholes for water, 42 percent get their water from the CRSWBL pipe borne water service, 4 percent get water from hand dug wells while 5 percent of the residents get their water from stream/river. Collection and distribution of water in the Municipality is the task of CRSWBL. CRSWBL was commissioned to control, manage and develop new water works and to provide sufficient water to cater for the water needs of residents of the area at economic charges. With more than half of the residents in the city using alternate sources from the CRSWBL service, it means there is a dearth in their service.

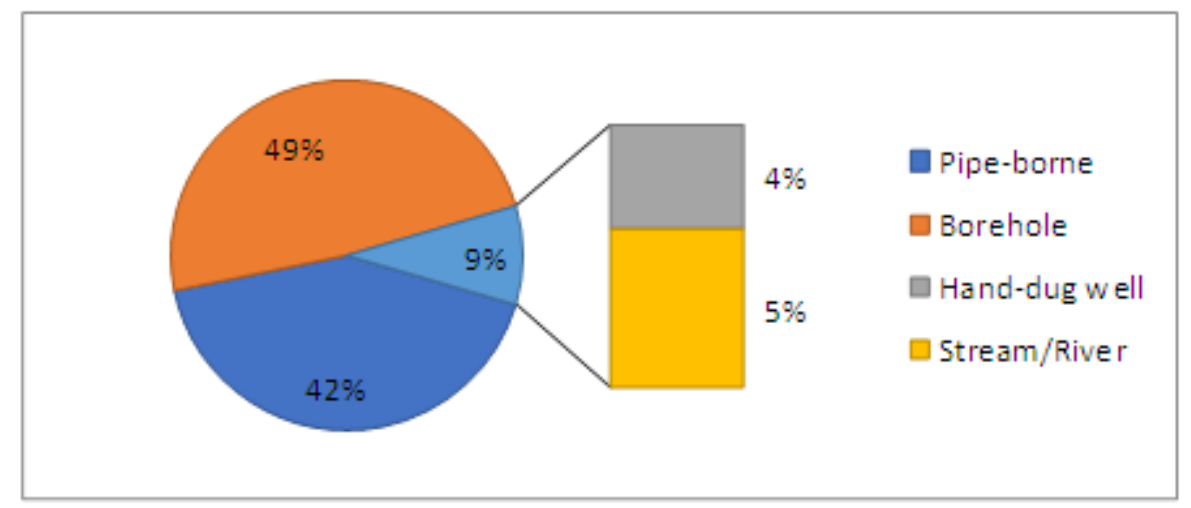

Figure 5. Sources of water supply in the study area (Source: Authors fieldwork, 2015) 
Philip O. Ubugha et al.

\subsection{Expenditure on Water}

Further analysis unveils the monthly expenses made by the residents on water. While 36.2 percent of households do not spend above 2000 naira, 28.4 percent spend between 2100 to 3000 naira, 26.0 percent spend between 3100 to 4000 naira and 9.4 percent spend more than 4000 naira. This indicates that the expenditure on water is high in the study area. The output of the Chi-square analyses executed to assess the relationship between income of respondents and expenditure on water shows that the Pearson Chi-square statistic $(f)=63.58, p$-value $=0.00(p<0.05)$. A lesser p-value implies that the variables are dependent, thus a significant statistical relationship exist between income and expenditure on water in the Municipality. Expenditure on water as buttressed by the Chi-square test is influenced by the income of the residents. Residents with higher income invariably spend more on water and vice-versa and expectedly, income would as well influence the volume of water used by respondents.

Table 1. Chi-square test for income versus expenditure on water

\begin{tabular}{|l|r|r|r|}
\hline & Value & df & Asymp. Sig. (2-sided) \\
\hline Pearson Chi-Square & $63.587^{\mathrm{a}}$ & 20 & .000 \\
\hline Likelihood Ratio & 55.393 & 20 & .000 \\
\hline Linear-by-Linear Association & 10.766 & 1 & .001 \\
\hline N of Valid Cases & 384 & & \\
\hline
\end{tabular}

Source: Authors fieldwork, 2015

In the same vein, Figure 6 is the spatial interpolation result of the average monthly expenditure on water by the Municipality residents. The result revealed that the highest expenditures of more than 4000 Naira were made by households in Ward 5, 7 and 9, while the least expenditures of less than 2000 Naira were made by households in Wards 1, 2, 3, 6 of Calabar Municipality.

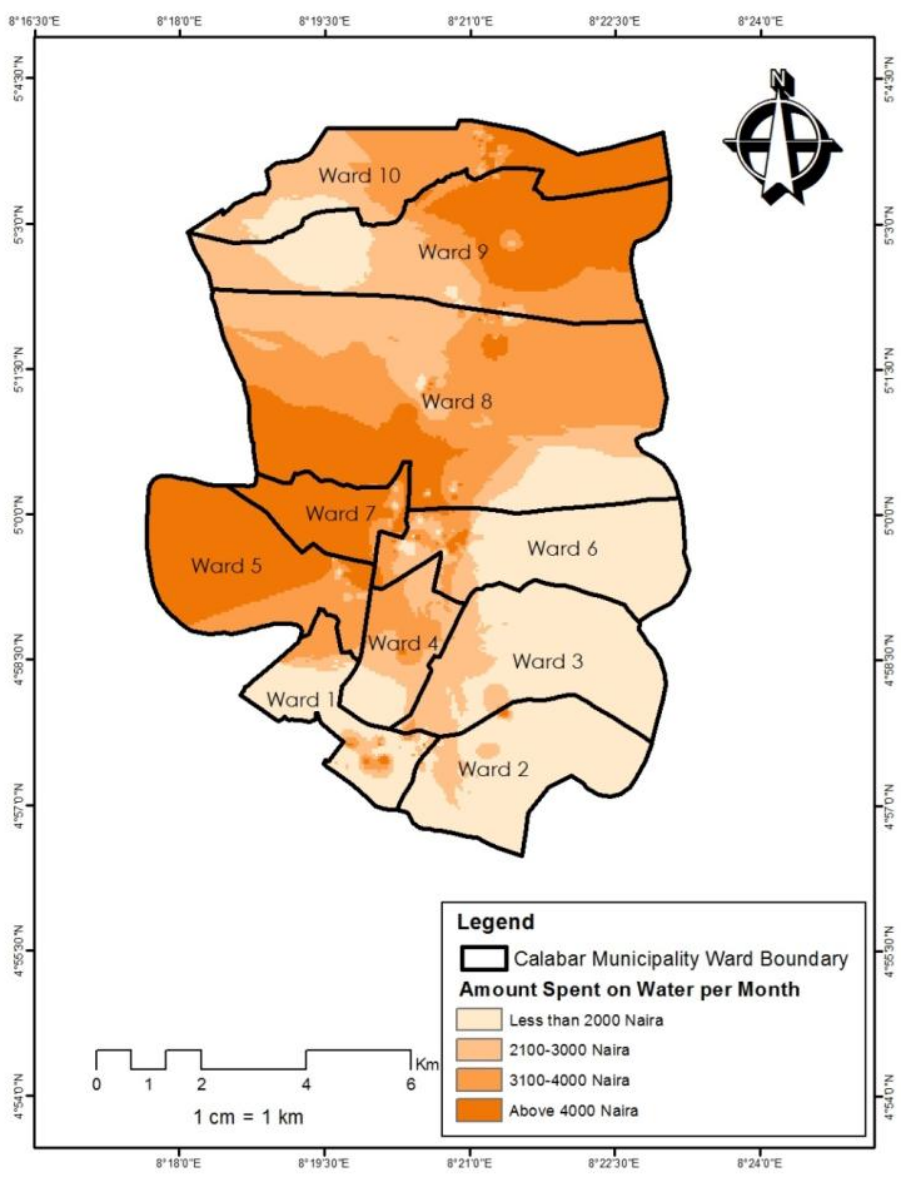

Figure 6. Map showing amount spent on water per month (Source: Authors fieldwork, 2015)

\subsection{Average Daily Water Used by Households}

Figure 7 shows the average volume of water consumed by households in the Municipality daily. It reveals that 26.3 percent of the households consume between 151 to 200 litres of water per day, 24.7 
percent use between 101 to 150 litres, 20.6 percent uses between 51 to 100 litres per day. Households that do not use more than 50 litres are 16.7 percent while 11.7 percent of the households use above 200 litres. This is a pointer to the fact that there is water problem in Calabar Municipality. This is against basic water requirement (BWR) of 50 litres of water per individual per day recommended by the World Health Organization (2003), especially as 82 percent of households in the area had more than 1 person. Likewise, Figure 8 shows the interpolated surface of the average daily water volume consumed in Calabar Municipality in 2015. The result revealed that residents in ward 2 and 3 consumed the least volume of water while few residents in ward 1, 4 and 7 consumed the highest.

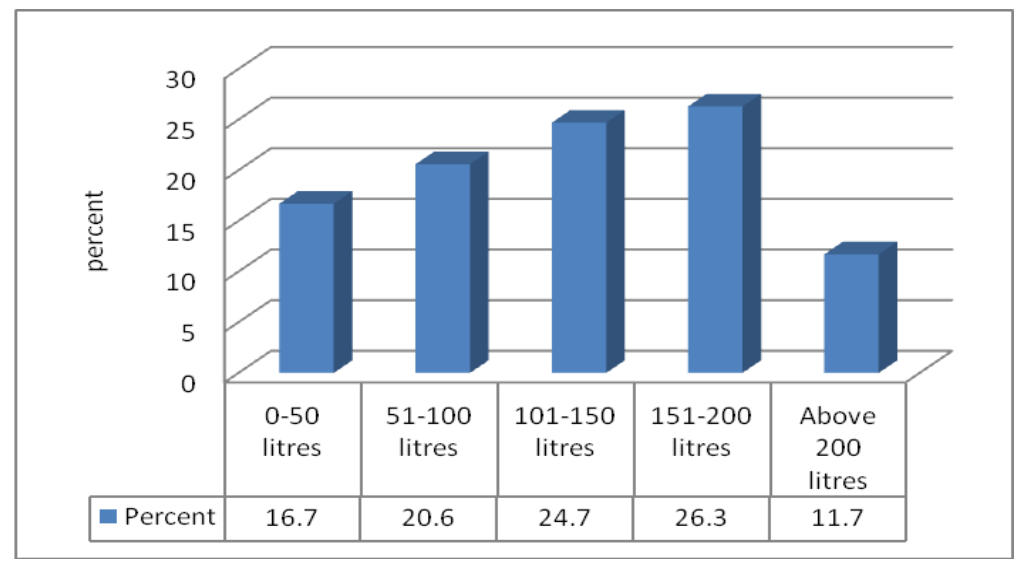

Figure 7. Average quantity of water consumed by households daily (Source: Authors fieldwork, 2015)

Additionally, the multinomial regression was used to test whether demographic and socio-economics factors influenced water use in Calabar Municipality. The factors considered include household size, literacy level, income and cost of 20 litre volume of water in 2015. From the analysis, the factor(s) that show significance would imply having significant relationship with water use in the area. As shown in table 7 , the likelihood ratio table below showed that household size was significant $(\mathrm{df}=24$, $\mathrm{p}=0.00$ ) which means that a larger house consumes more water than a household with a fewer members. On the other hand, education was not significant $(\mathrm{df}=16, \mathrm{p}=0.93)$ The implication of this result is that literacy level of an individual or household does not influence water use in Calabar Municipality. Again, income was significant $(\mathrm{df}=20, \mathrm{p}=0.03)$ meaning that the rich people use more water than poor and lastly, cost of water was also significant $(\mathrm{df}=16, \mathrm{p}=0.028)$ pointing to the fact that the where water is affordable, usage would be high by the residents. Table 7 shows the likelihood table of the regression analysis.

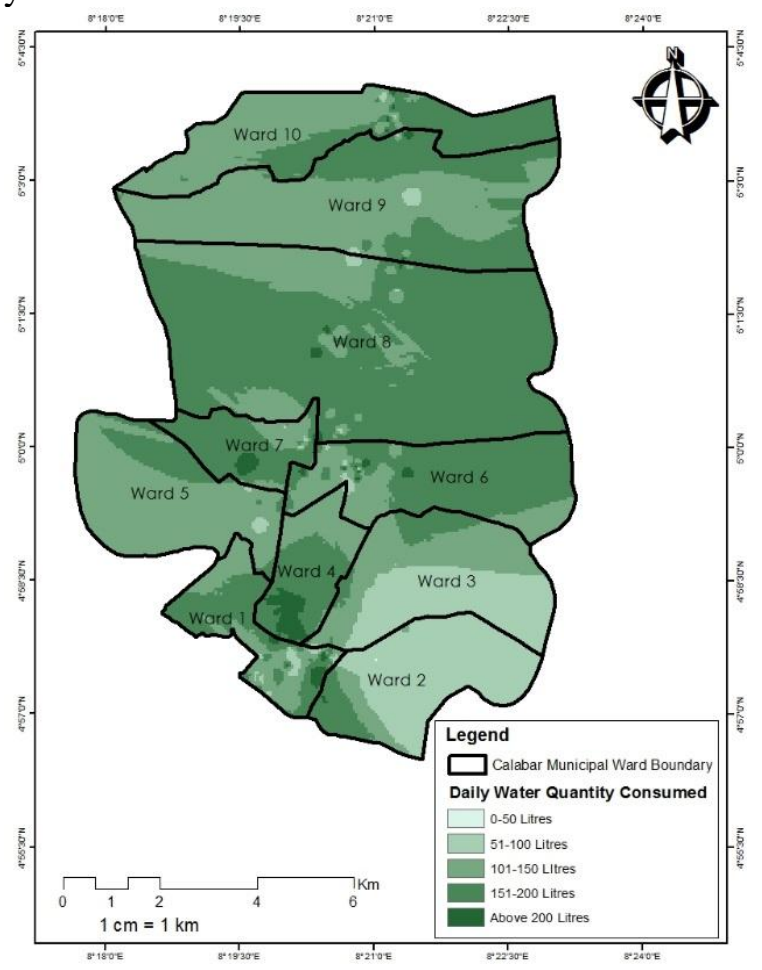

Figure 8. Map showing daily water quantity consumed (Source: Authors fieldwork, 2015) 
Philip O. Ubugha et al.

Table 7. Likelihood Ratio Tests

\begin{tabular}{|l|r|r|r|r|}
\hline \multirow{2}{*}{ Effect } & \multicolumn{1}{|c|}{ Model Fitting Criteria } & \multicolumn{2}{|c|}{ Likelihood Ratio Tests } \\
\cline { 2 - 5 } & \multicolumn{1}{|c|}{ Log Likelihood of Reduced } & \multicolumn{1}{c|}{ Chi-Square } & \multicolumn{1}{c|}{ Df } & \multicolumn{1}{c|}{ Sig. } \\
\hline Intercept & $703.452^{\mathrm{a}}$ & .000 & 0 &. \\
\hline Household Size & 784.618 & 81.167 & 24 & .000 \\
\hline Education & 727.297 & 23.845 & 16 & .093 \\
\hline Income & $736.241^{\mathrm{b}}$ & 32.790 & 20 & .036 \\
\hline Cost_20litres_Water_ & 731.883 & 28.431 & 16 & .028 \\
\hline
\end{tabular}

Source: Authors fieldwork, 2015

\subsection{Population Growth and CRSWBL Pipe-Borne Water Consumption}

The relationship between population growth and CRSWBL pipe-borne water consumption in Calabar municipality from 2006 to 2015 was examined empirically. The yearly volume of water consumed by the residents given by CRSWBL for the period under review and the projected population is shown in Table 8. As presented, there was a gradual increase in the volume of water consumed from 2006 to 2015. A total of $3,438,738 \mathrm{~m}^{3}$ was consumed in 2006 and a graduation to $4,044,711 \mathrm{~m}^{3}$ in 2015 . Also, based on a projection of the population of the Municipality, the population of the area in 2006 stood at 188424 and 221628 in 2015.The Pearson's product moment correlation coefficient output in Table 9 showed that there was statistical significant relationship between population growth and pipe-borne water consumption in Calabar Municipality from 2006 to 2015 ( $\mathrm{p}=0.00<0.05$ ). This is an implication that population growth affects water consumption in the area. As population increased in the area, water consumption as well increased significantly.

Table 8. Population and volume of water consumed from 2006 to 2015

\begin{tabular}{|c|c|c|}
\hline Year & Population & Volume of water Consumed $\left(\mathrm{m}^{3}\right)$ \\
\hline 2006 & 188424 & $3,438,738$ \\
\hline 2007 & 193896 & $3,538,602$ \\
\hline 2008 & 197362 & $3,601,874$ \\
\hline 2009 & 200829 & $3,665,129$ \\
\hline 2010 & 204295 & $3,728,383$ \\
\hline 2011 & 207762 & $3,790,656$ \\
\hline 2012 & 211229 & $3,854,929$ \\
\hline 2013 & 214695 & $3,918,180$ \\
\hline 2014 & 218162 & $3,981,456$ \\
\hline 2015 & 221628 & $4,044,711$ \\
\hline
\end{tabular}

Source: NPC, 1991, CRSWBL, 2015 and Authors fieldwork, 2015

Table 9. Correlation output for population versus volume of water consumed

\begin{tabular}{|l|l|r|r|}
\hline \multicolumn{2}{|c|}{} & Population & \multicolumn{1}{|c|}{ Consumption } \\
\hline \multirow{4}{*}{ Population } & Pearson Correlation & 1 & $1.000^{* *}$ \\
\cline { 2 - 4 } & Sig. (2-tailed) & 10 & .000 \\
\cline { 2 - 4 } & $\mathrm{N}$ & $1.000^{* *}$ & 10 \\
\hline \multirow{3}{*}{ Consumption } & Pearson Correlation & .000 & 1 \\
\cline { 2 - 4 } & Sig. (2-tailed) & 10 & 10 \\
\cline { 2 - 4 } & $\mathrm{N}$ & & \\
\hline \multirow{2}{*}{$* *$ Correlation is significant at the 0.01 level (2-tailed). } & \multicolumn{2}{|c}{} \\
\hline
\end{tabular}

Source: Authors fieldwork, 2015

\subsection{Population Growth and CRSWBL Pipe-Borne Water Supply}

Also, the relationship between population growth and pipe-borne water supply in Calabar municipality from 2006 to 2015 was studied. The yearly volume of water supplied by the water board for the period under review and the projected population is shown in Table 10. As shown, there was a steady increase in the volume of water supplied from 2006 to 2015 . A total of $2435674.32 \mathrm{~m}^{3}$ was 
supplied in 2006 and a graduation to $5793039.6 \mathrm{~m}^{3}$ in 2014, although there were shortfalls in supply in 2009 and 2010. The Municipality again experienced a shortfall in 2015 when the volume supplied reduced to $4132669.2 \mathrm{~m}^{3}$. The output of the Pearson's correlation analysis in Table 11 showed that there was significant statistical relationship between pipe-borne water supply and population growth in Calabar Municipality during the period $(\mathrm{p}=0.002<0.05)$. This implies that over time, water supplied by CRSWBL increased and the population of the Municipality increased as well. Earlier findings in in this study has shown that this accompanying increase in supply is not commensurate with the water demands of the people as only 42 percent of residents rely on CRSWBL pipe-borne water due to its unavailability, 36 percent travel more than $200 \mathrm{~m}$ to acquire water and only few households have sufficient water for daily use.

Table 10. Population and volume of pipe borne water supply from 2006 to 2015

\begin{tabular}{|l|l|c|}
\hline Year & Population & Volume of Water Supplied $\left(\mathrm{m}^{3}\right)$ \\
\hline 2006 & 188424 & 2435674.32 \\
\hline 2007 & 193896 & 2597319 \\
\hline 2008 & 197362 & 3373241.4 \\
\hline 2009 & 200829 & 3093185.4 \\
\hline 2010 & 204295 & 3133953.6 \\
\hline 2011 & 207762 & 3972873 \\
\hline 2012 & 211229 & 4890627.6 \\
\hline 2013 & 214695 & 5073651.6 \\
\hline 2014 & 218162 & 5793039.6 \\
\hline 2015 & 221628 & 4132669.2 \\
\hline
\end{tabular}

Source: NPC, 1991, CRSWBL, 2015, and Author's field work, 2015.

Table 9. Correlation output for population versus volume of water supplied

\begin{tabular}{||l|l|l|}
\hline & Population & Water Supply \\
\hline Pearson Correlation & 1 & $.855^{* *}$ \\
\hline Sig. (2-tailed) & & .002 \\
\hline $\mathrm{N}$ & 10 & 10 \\
\hline & .855 & 1 \\
\hline & .002 & \\
\hline & 10 & 10 \\
\hline
\end{tabular}

Source: Authors fieldwork, 2015

\subsection{Overview of Water Situation in the Study Area}

An overview of the water situation in the area showed that 45.3 percent of the respondents agreed that access to water is adequate in the Municipality, 35.7 percent maintained that it is inadequate. Also, 11.4 percent held that the situation was commendable and thus very adequate while 7.6 percent lamented a dire, very inadequate situation. Plates 1 and 2 pictures residents of Big Qua Town and Joseph Mkpang Street, Ikot Ansa respectively waiting for their turn to fetch water at privately owned boreholes.

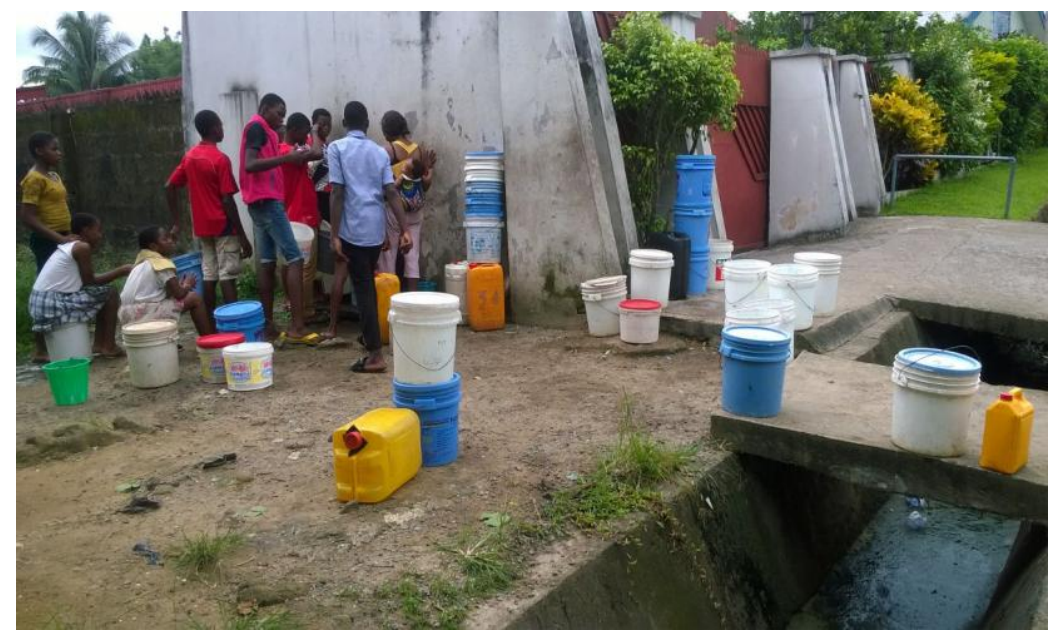

Plate 1. Residents of Big Qua Town waiting for their turn to fetch water (Source: Authors fieldwork, 2015) 


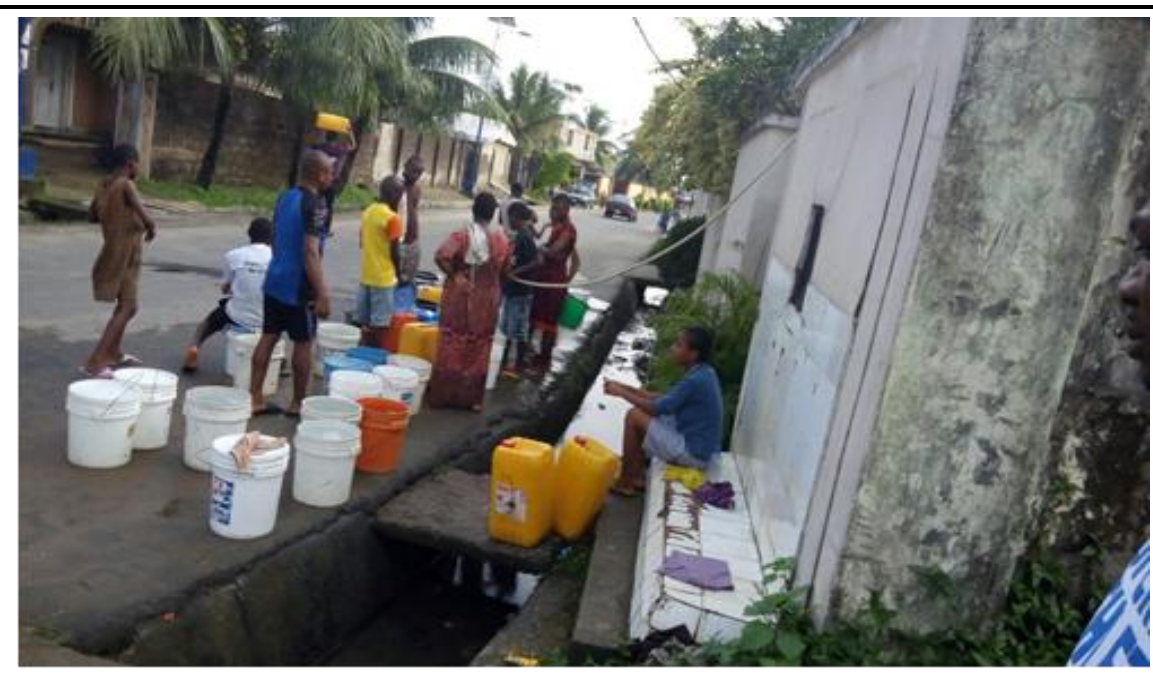

Plate 2. Residents waiting to fetch water at Joseph Mkpang Street, Ikot Ansa (Source: Authors fieldwork, 2015)

\section{CONCLUSION}

The world needs nothing less than a blue revolution. A better approach to water management that takes account of the needs of various users and apportions water sustainably and efficiently, vital for the well-being of all.In line with this, this study centred on the status quo of people and water in Calabar Municipality, Cross River State, Nigeria. Results from the study revealed that population growth which was evident in the Municipality influenced on water availability and consumption. There was dearth in water availability and geographic access to water showed to be limited in the Municipality. Household size, income and cost of water also had significant relationships with water use in the area. The issue of water in the study area is not a budding problem, thus requires a pragmatic approach to forestall devastating effects in the near future.

\subsection{Recommendation}

i. There is need for new policies by the government and particularly the CRSWBL for managing water resources and ensuring sustainability in the process of collecting, processing and distributing water.

ii. To ensure that CRSWBL that is saddled with the responsibility of providing portable water in the Municipality is well funded, water should be treated as an economic good. Water rates should be paid promptly to enable the organization maintains its facility and take care of welfare of her staff for efficient and effective service delivery. The water management authority should operate a strong and an incorruptible task force that will monitor compliance level and effect disconnection to defaulting residents and/or customers. Consequent to this, CRSWBL must be diligent in its service to ensure efficiency and effectiveness.

iii. With the population increase evident in the Municipality, relevant agencies should take necessary measures at stabilizing the population, such as sensitizing the people on the need to have a population that would assert less pressure on families and the society at large. Pressure on the society in this regard would imply stress on the water company and on other available sources of water

iv. Communities in Calabar Municipality should embark on self-help water projects. This can be done by individuals in the communities of by the people in partnership with the government or any other Social Development Agency. An example is a counterpart funded project where the community pays a percent of the total cost required for providing water or provides necessary good or services such as such as gravel, sand, water and labour. If community water project is completed and properly managed, it will reduce the problem of water availability, accessibility and cost in the study area.

v. Recent geospatial technologies such as GIS tools should be adopted for water management and planning to aid in decision making which is the essence of every GIS. 


\section{REFERENCES}

Bates, B.C., Kundzewicz, Z.W., Wu S. \& Palutikof J.P. (2008). Climate Change and Water: Technical Paper of the Inter-governmental Panel on Climate Change. Geneva.

Bello, N. I. \& Tuna, F. (2014). Evaluation of Potable Water Demand and Suply in Kano State, Nigeria. International Journal of Scientific Knowledge, 4(6).

Eni, D. I., Digha, O. N. \& Abua, M. (2015) Spatio-Temporal variability in Domestic Water Demand and Supply in Calabar Metropolis. International Journal of Research in Environmental Science (IJRES), 1(1):20-29.

Eni, E. B. (2010). M.Sc Thesis on Domestic Water Supply in Abi Local Government Area Problems and Prospects.

ESRI (2013). An introduction to interpolation methods, ArcGIS for Desktop Help, 1995-2013.

Ezenwaji E. E., Eduputa B. M. \& Okoye, C. O. (2016). Investigations into the Residential Water Demand and Supply in Enugu Metropolitan Area Nigeria. American Journal of Water Resources, 4(1): 22-29.

Farnazeh, R. (2001) "Population Trends and Challenges in the Middle East and North Africa" (Washington, DC: Population Reference Bureau 2001).

Human Development Report (2006). Beyond scarcity; power, poverty, and global water crises. Published for United Nation Development Programme, 113-170.

Nhapi, I. (2009). M.Sc Thesis on the water situation in Harare, Zimbabwe: A policy and management problem. Faculty of Applied Sciences, National University of Rwanda, Bature, Rwanda.

Njoku, C. G, Okon, I., Okpiliya, F., Agbor, E. A \& Ekwok, I. (2017). Epanet spatial modeling for equitable pipe-borne water distribution in Calabar Metropolis, Cross River State, Southern Nigeria. International Journal of Science, Environment and Technology. 6 (4).

Oyegoke, S. O., Adeyemi, O. \& Sojobi, A. O. (2012). The challenges of water supply for a magacity: A case study of Lagos Metropolis. International Journal of Scientific and Engineering Research, $3(2)$.

Population Action International (2011). Why Population Matters to Water Resources, Retrieved March, 2016 from: pai.org/wp-content/upload/2012/04/PAI-1293-WATER-4PG.pdf

Population Institute (2010). Population and Water: World water stress and water scarce.

Smith, S. M. (2000). Determining sample size: how to ensure you get the correct sample size. Retrieved February, 2016 from http://success.qualtrics.com/rs/qualtrics/images/determiningsample-size.pdf

United Nations Population Division (2006). Population Reference Bureau. World Population prospects 2006.

United Nations Population Division (2008), Population Reference Bureau. World Population Prospects. The 2008 Revision.

UNPD (2000). Charting the Progress of Populations, Pg 67, 71. Retrieved November, 2015 from http://www.un.org/en/development/desa/population/publications/pdf/trends/progressofpopulation $\mathrm{s} / 12$.pdf

WHO (2003). The Right to Water. Office of the High Commissioner for Human Rights (OHCHR), Centre on Housing Rights and Evictions (COHRE), Water Aid, Centre on Economic, Social and Cultural Rights. Retrieved July, 2016 from http://www2.ohchr.org/english/issues/water/docs/ Right_to_Water.pdf 